\title{
A STUDY OF THE BLOOD IODINE IN CHILDHOOD
}

\author{
By GLADYS J. FASHENA \\ (From the New York Hospital and the Department of Pediatrics, Cornell University Medical \\ College, New York City)
}

(Received for publication December 22, 1937)

The recent development of adequate techniques for the microdetermination of iodine in biological material has given impetus to the study of iodine metabolism in health and disease. Within the past ten years many studies of the range of blood iodine in normal and pathological conditions have appeared in the literature $(1,2)$. Unfortunately, the " normal" whole blood iodine values given by various authors vary widely, ranging from an average of 4.3 micrograms per $100 \mathrm{cc}$. of blood reported by Fowweather (3) to Widmann's (4) reported average of 32 micrograms per $100 \mathrm{cc}$. Such wide discrepancies may be attributable, in part, to different analytical methods employed and partly to varying locale. In spite of the lack of agreement upon a normal blood iodine milieu, most authors concur in finding a frequent correlation, although by no means an absolute parallelism, between the level of iodine in the blood and the functional activity of the thyroid gland.

The present study was undertaken: 1 , to establish, in the absence of adequate normal standards for blood iodine in children, such norms on a large number of subjects; 2 , to investigate the effect of a number of variables such as age, type of feeding, season and fever on the level of blood iodine in these subjects in an effort to define optimal conditions for making analyses; 3 , to assay the diagnostic possibilities of the blood iodine in thyroid disturbances. The latter is of special interest since direct metabolic measurements are technically difficult in infants and young children.

\section{SUBJECTS}

One hundred well children, from birth to 13 years of age, were used as normal subjects in this study. The 41 infants were born in the Lying-In Pavilion of the New York Hospital of mothers who had had uncomplicated pregnancies and uneventful deliveries, with nitrous oxideether as anesthetics. No iodine in any form was used in the preparation of the mothers for delivery. The older children were well patients in the Children's Clinic of the New York Hospital. No medication was administered to any of the subjects with the exception of cod liver oil which was given to 19 children, as indicated in Table I. A careful attempt was made to investigate the dietary and habits of all subjects for occult sources of iodine intake.

\section{METHOD}

A score of iodine micromethods have appeared in the literature within the past ten years, each with its enthusiastic proponents. The wide discrepancies in reported blood iodine figures probably depend in large measure upon variations in these methods. It seems reasonable to suppose in the case of blood iodine, as in the case of blood sugar and blood urea, that the method which yields satisfactory recoveries of many different types of iodine compounds both in pure solution and when added to blood, and at the same time gives the lowest values for blood alone, may be assumed to portray most accurately the level of iodine in the blood. The method of Trevorrow and Fashena $(5,6)$, which fulfills these conditions, was employed in this study. Approximately two thousand analyses have been made with this method with an average error of less than ten per cent. A detailed description of the analytical procedure was given in previous papers $(5,6)$. Briefly, the method consists of chrom-sulfuric acid oxidation of the organic matter with subsequent boiling to rid the digest of chromyl chloride and acetic acid. Phosphorous acid is then added and the iodine distilled out of the mixture in an all-glass apparatus. After acidification, bromination and evaporation of the distillate, the iodine is titrated by the Winkler technique, using $\mathrm{N} / 1000$ sodium thiosulfate. All reagents were carefully purified and blank determinations, using the reagents alone, yielded no chromogenic material whatever in the final titration. All purifications and analyses were carried out by the writer in a special room set aside only for this purpose.

Meticulous care was taken to avoid contamination with iodine in the collection and preparation of blood samples. The skin was prepared with iodine-free alcohol and the blood drawn with special syringes and needles which were used for this work alone. The samples were placed in chemically clean flasks and oxalated with recrystallized potassium oxalate. Duplicate samples were analyzed whenever possible, but in cases where only 10 to 15 cc. of blood were obtained, single analyses were deemed more accurate than duplicate analyses on divided samples, since the latter might contain as little as 0.2 microgram of iodine.

The magnitude of accuracy in expressing the results for blood iodine in terms of micrograms per $100 \mathrm{cc}$. should be mentioned. It will be noted that the figures 
TABLE I

Blood iodine values of normal children in New York City *

\begin{tabular}{|c|c|c|c|c|c|c|c|}
\hline Case & Date & Sex & Age & Diet & $\begin{array}{c}\text { Cod liver } \\
\text { oil }\end{array}$ & $\begin{array}{l}\text { Time of col- } \\
\text { lections after } \\
\text { feeding }\end{array}$ & $\begin{array}{c}\text { Blood } \\
\text { iodine† }\end{array}$ \\
\hline $\begin{array}{r}1 \\
2 \\
3 \\
4 \\
5 \\
6 \\
7 \\
8 \\
9 \\
10 \\
11 \\
12 \\
13 \\
14 \\
15 \\
16 \\
17 \\
18 \\
19 \\
20 \\
21\end{array}$ & $\begin{array}{l}\text { March } 13,1937 \\
\text { March } 18,1937 \\
\text { March } 24,1937 \\
\text { May } 14,1937 \\
\text { May } 14,1937 \\
\text { May } 10,1937 \\
\text { May } 7,1937 \\
\text { May } 12,1937 \\
\text { May } 15,1937 \\
\text { May } 10,1937 \\
\text { May } 15,1937 \\
\text { May } 17,1937 \\
\text { May } 18,1937 \\
\text { May } 9,1937 \\
\text { May 8, } 837 \\
\text { March 8, } 1937 \\
\text { May } 13,1937 \\
\text { May } 13,1937 \\
\text { May } 14,1937 \\
\text { March 8, } 1937 \\
\text { May } 19,1937\end{array}$ & $\begin{array}{l}\text { F. } \\
\text { M. } \\
\text { M. } \\
\text { M. } \\
\text { F. } \\
\text { M. } \\
\text { F. } \\
\text { F. } \\
\text { M. } \\
\text { F. } \\
\text { F. } \\
\text { F. } \\
\text { F. } \\
\text { F. } \\
\text { M. } \\
\text { F. } \\
\text { M. } \\
\text { F. } \\
\text { F. }\end{array}$ & $\begin{array}{l}\text { Placental blood } \\
\text { Placental blood } \\
\text { Placental blood } \\
2 \frac{1}{4} \text { hours } \\
2 \frac{1}{4} \text { hours } \\
2 \frac{1}{2} \text { hours } \\
3 \text { hours } \\
3 \text { hours } \\
3 \frac{1}{2} \text { hours } \\
4 \text { hours } \\
5 \text { hours } \\
5 \text { hours } \\
6 \text { hours } \\
8 \text { hours } \\
10 \text { hours } \\
10 \text { hours } \\
10 \text { hours } \\
13 \frac{1}{2} \text { hours } \\
14 \text { hours } \\
14 \text { hours } \\
15 \text { hours }\end{array}$ & \begin{tabular}{l}
\multicolumn{1}{c}{0} \\
0 \\
0 \\
0 \\
0 \\
0 \\
0 \\
0 \\
0 \\
0 \\
0 \\
0 \\
0 \\
0 \\
Lactose water \\
Lactose water \\
Lactose water \\
Lactose water \\
Lactose water \\
Lactose water \\
Breast \\
Lactose water
\end{tabular} & $\begin{array}{l}0 \\
0 \\
0 \\
0 \\
0 \\
0 \\
0 \\
0 \\
0 \\
0 \\
0 \\
0 \\
0 \\
0 \\
0 \\
0 \\
0 \\
0\end{array}$ & $\begin{array}{l}\text { No food } \\
\text { No food } \\
\text { No food } \\
\text { No food } \\
\text { No food } \\
\text { No food } \\
\text { No food } \\
\text { No food } \\
\text { No food } \\
\text { No food } \\
\text { No food } \\
\text { No food } \\
\text { No food } \\
1 \text { hour p.c. } \\
2 \text { hours p.c. } \\
3 \text { hours p.c. } \\
1 \text { hour p.c. } \\
2 \text { hours p.c. } \\
1 \text { hour p.c. } \\
\text { Immediate p.c. } \\
2 \text { hours p.c. }\end{array}$ & 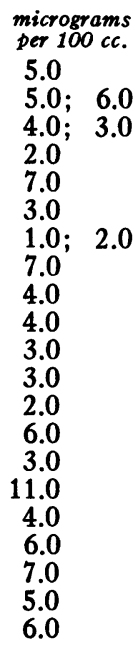 \\
\hline $\begin{array}{l}22 \\
23 \\
24 \\
25 \\
26 \\
27 \\
28 \\
29 \\
30 \\
31 \\
32 \\
33 \\
34 \\
35 \\
36 \\
37 \\
38 \\
39 \\
40 \\
41 \\
42 \\
43 \\
44 \\
45 \\
46 \\
47 \\
48 \\
49 \\
50 \\
51 \\
52 \\
53 \\
54 \\
55 \\
56 \\
57 \\
58 \\
59 \\
60\end{array}$ & 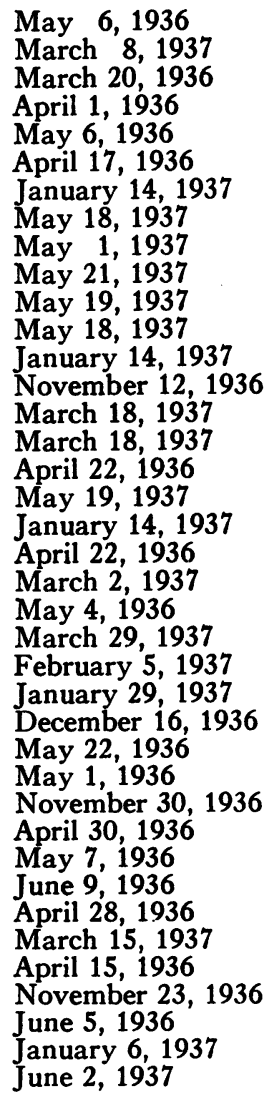 & $\begin{array}{l}\text { F. } \\
\text { F. } \\
\text { F. } \\
\text { F. } \\
\text { M. } \\
\text { F. } \\
\text { F. } \\
\text { F. } \\
F . \\
F . \\
F . \\
F . \\
\text { M. } \\
\text { F. } \\
\text { M. } \\
\text { M. } \\
\text { F. } \\
\text { F. } \\
\text { M. } \\
\text { M. } \\
\text { F. } \\
\text { M. } \\
\text { M. } \\
\text { F. } \\
\text { M. } \\
\text { M. } \\
\text { F. } \\
\text { F. } \\
\text { M. }\end{array}$ & $\begin{array}{l}2 \text { days } \\
3 \text { days } \\
5 \text { days } \\
5 \text { days } \\
5 \text { days } \\
6 \text { days } \\
6 \text { days } \\
8 \text { days } \\
9 \text { days } \\
9 \text { days } \\
9 \text { days } \\
9 \text { days } \\
9 \text { days } \\
9 \text { days } \\
10 \text { days } \\
10 \text { days } \\
10 \text { days } \\
11 \text { days } \\
11 \text { days } \\
11 \text { days } \\
2 \text { weeks } \\
2 \text { weeks } \\
3 \text { weeks } \\
3 \text { weeks } \\
3 \text { weeks } \\
3 \text { weeks } \\
3 \text { weeks } \\
3 \text { weeks } \\
4 \text { weeks } \\
5 \text { weeks } \\
5 \text { weeks } \\
5 \text { weeks } \\
6 \text { weeks } \\
2 \text { months } \\
3 \text { months } \\
4 \text { months } \\
5 \text { months } \\
5 \text { months } \\
6 \text { months }\end{array}$ & $\begin{array}{l}\text { Breast } \\
\text { Breast } \\
\text { Breast } \\
\text { Breast } \\
\text { Breast } \\
\text { Mixed feeding } \\
\text { Breast } \\
\text { Breast } \\
\text { Mixed feeding } \\
\text { Breast } \\
\text { Breast } \\
\text { Breast } \\
\text { Breast } \\
\text { Mixed feeding } \\
\text { Mixed feeding } \\
\text { Breast } \\
\text { Breast } \\
\text { Mixed feeding } \\
\text { Breast } \\
\text { Breast } \\
\text { Breast } \\
\text { Mixed feeding } \\
\text { Breast } \\
\text { Breast } \\
\text { Breast } \\
\text { Breast } \\
\text { Breast } \\
\text { Breast } \\
\text { Breast } \\
\text { Cow's milk } \\
\text { Mixed feeding } \\
\text { Mixed feeding } \\
\text { Mixed feeding } \\
\text { Evaporated milk } \\
\text { Cow's milk } \\
\text { Mixed feeding } \\
\text { Mixed feeding } \\
\text { Mixed feeding } \\
\text { Infant diet }\end{array}$ & $\begin{array}{c}0 \\
0 \\
0 \\
0 \\
0 \\
0 \\
0 \\
0 \\
0 \\
0 \\
0 \\
0 \\
0 \\
0 \\
0 \\
0 \\
0 \\
0 \\
0 \\
0 \\
0 \\
0 \\
0 \\
0 \\
0 \\
0 \\
0 \\
0 \\
0 \\
0 \\
4 \text { cc. } \text { q.d. } \\
0 \\
0 \\
0 \\
10 \text { cc. } \text { q.d.d. } \\
0 \\
0 \\
0 \\
12 \text { cc. q.d. }\end{array}$ & $\begin{array}{l}2 \text { hours p.c. } \\
\text { Immediate p.c. } \\
\frac{1}{2} \text { hour p.c. } \\
2 \frac{1}{2} \text { hours p.c. } \\
2 \text { hours p.c. } \\
1 \frac{1}{2} \text { hours p.c. } \\
1 \text { hour p.c. } \\
3 \text { hours p.c. } \\
1 \text { hour p.c. } \\
\text { Immediate p.c. } \\
3 \text { hours p.c. } \\
1 \text { hour p.c. } \\
1 \frac{1}{2} \text { hours p.c. } \\
4 \text { hours p.c. } \\
4 \text { hours p.c. } \\
\frac{1}{4} \text { hour p.c. } \\
1 \text { hour p.c. } \\
1 \text { hour p.c. } \\
\frac{1}{4} \text { hour p.c. } \\
2 \text { hours p.c. } \\
3 \frac{1}{2} \text { hours p.c. } \\
3 \text { hours p.c. } \\
1 \frac{1}{2} \text { hours p.c. } \\
4 \text { hours p.c. } \\
5 \text { hours p.c. } \\
3 \frac{1}{2} \text { hours p.c. } \\
4 \frac{1}{2} \text { hours p.c. } \\
3 \frac{1}{2} \text { hours p.c. } \\
5 \text { hours p.c. } \\
4 \text { hours p.c. } \\
\text { Immediate p.c. } \\
4 \text { hours p.c. } \\
3 \text { hours p.c. } \\
4 \text { hours p.c. } \\
10 \text { hours p.c. } \\
\text { Immediate p.c. } \\
1 \text { hour p.c. } \\
\text { Fasting }\end{array}$ & $\begin{array}{cl}11.0 & \\
7.0 & \\
7.0 ; & 8.0 \\
7.0 & \\
8.0 & \\
8.0 & \\
3.0 \\
3.0 \\
6.0 \\
7.0 \\
5.0 \\
5.0 \\
8.0 \\
5.0 ; \quad 6.0 \\
4.0 ; 4.0 \\
8.0 \\
6.0 \\
3.0 \\
8.0 \\
8.0 ; 8.0 \\
8.0 & \\
4.0 & \\
7.0 & \\
4.0 & \\
9.0 & \\
8.0 & \\
10.0 & \\
12.0 ; & 12.0 \\
9.0 & \\
4.0 ; & 5.0 \\
7.0 & \\
6.0 & \\
8.0 ; & 8.0 \\
8.0 & \\
9.0 & \\
5.0 & \\
6.0 ; & 7.0 \\
5.0 & \\
3.0 & \end{array}$ \\
\hline
\end{tabular}


TABLE I-Continued

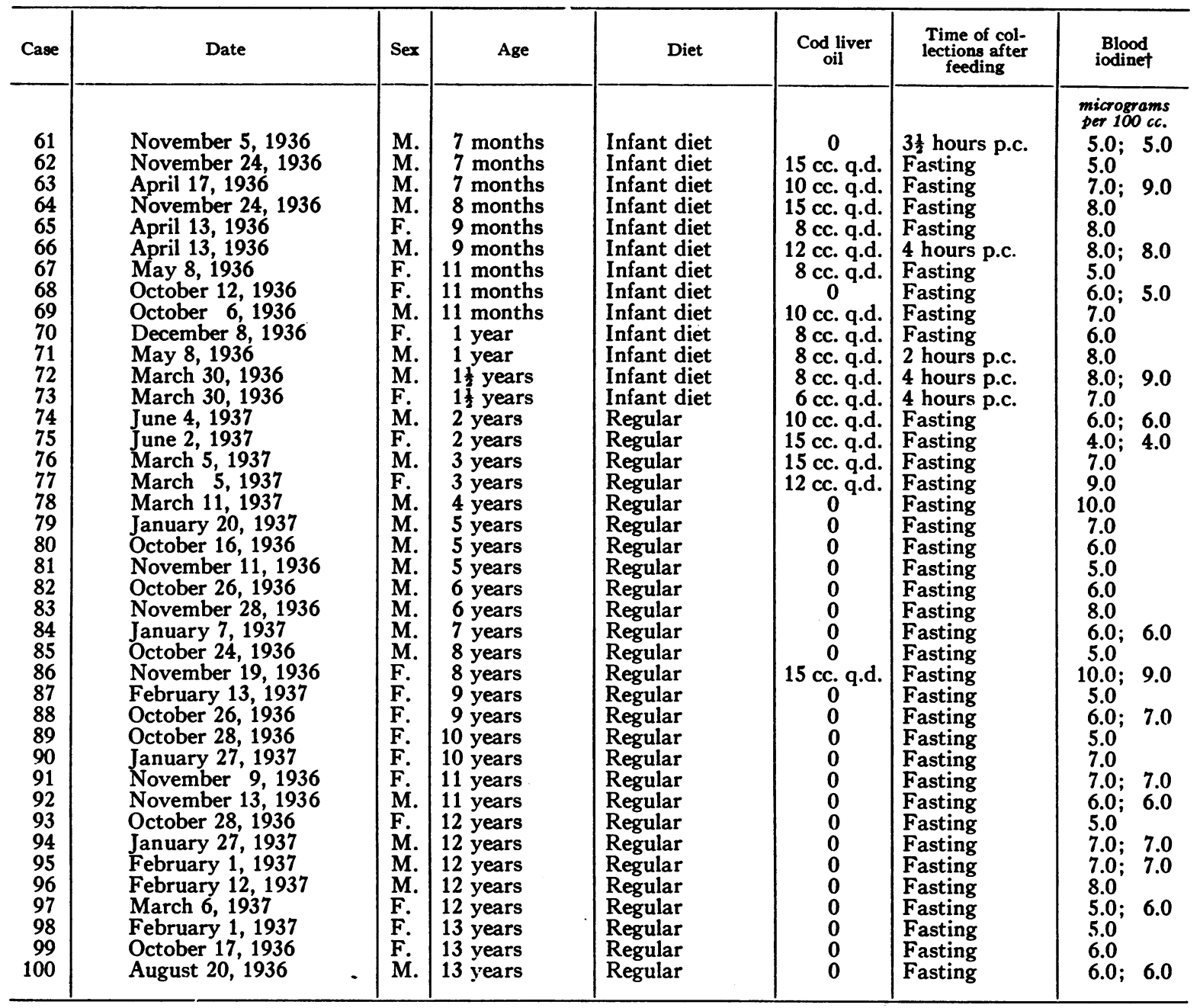

* The average blood iodine in subjects under 24 hours of age is 4.7 with a probable error of \pm 0.33 . The average value for the older subjects is 6.6 with a probable error of \pm 0.15 .

$\dagger$ Two figures denote duplicate analyses of the same sample.

herein reported are expressed in terms of the nearest whole number. The reason for this becomes clear if one inspects the conditions of the final titration, in which $\mathrm{N} / 1000$ sodium thiosulfate is used in a burette which delivers a drop $0.004 \mathrm{~cm}$. in size. Such a drop is equivalent to 0.084 microgram of iodine in the sample. Since most of the samples are approximately $10 \mathrm{cc}$., the value obtained must be multiplied by 10 to obtain the blood iodine in terms of micrograms per $100 \mathrm{cc}$. No figure for iodine in terms of micrograms per $100 \mathrm{cc}$. can therefore be accurate to within less than 0.8 of a microgram and decimals should be discarded in the final result as not being significant figures. ${ }^{1}$

1 The results were statistically analyzed according to standard procedure. The mean, standard deviation $\left(s=\sqrt{\left.\Sigma_{x^{2}} / n-1\right)}\right.$ probable error (P.E. $=0.6745$ $(s / \sqrt{n}))$, and for comparative purposes in the different

\section{RESULTS}

Detailed data for all subjects are presented in Table I. Low figures were found so frequently in subjects less than 24 hours old that the results for these 21 infants were treated as a group separate from the other cases. Although individual values for both this and the group of older subjects showed rather wide fluctuations, the respective ranges being 1.0 to 11.0 micrograms and 3.0 to 12.0 micrograms, the mean value for the blood iodine of infants under 24 hours of age was 4.7 \pm 0.33 micrograms per $100 \mathrm{cc}$. as compared with

age groups the probable error of the difference (P.E. diff. $=\sqrt{\left.\text { P.E. } x^{2}+\text { P.E. } y^{2}\right)}$ were calculated (7). 
a mean of $6.6 \pm 0.15$ for all the other cases. the direction of the lower quartile is due to the That this difference is significant is evident from inclusion of the 21 infants under 24 hours of age. a statistical comparison of the means, the differ- Graphic representation of successive determina-

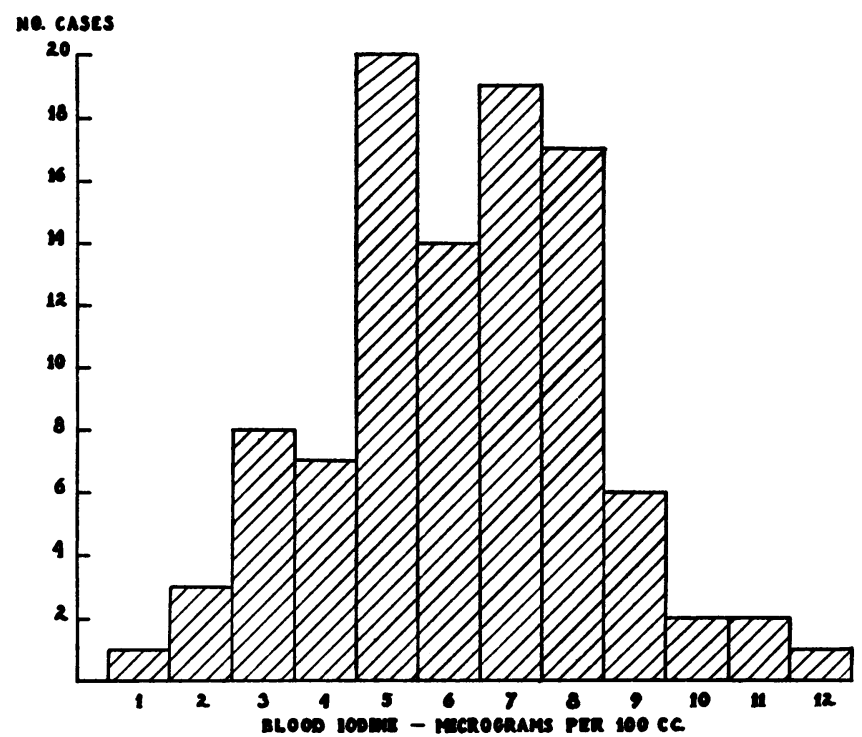

Fig. 1. Frequency Distrubution of Blood Iodine in 100 Normal Cases (Birth to 13 Years)

ence between the means (1.9) being over five tions of iodine on single infants demonstrates times the probable error of the difference $(0.36)$. more strikingly the progressive rise in blood iodine

The frequency distribution of the entire series in the first days of life (Figure 2). The blood is shown graphically in Figure 1 . The skew in iodine on succeeding estimations exceeded the in-

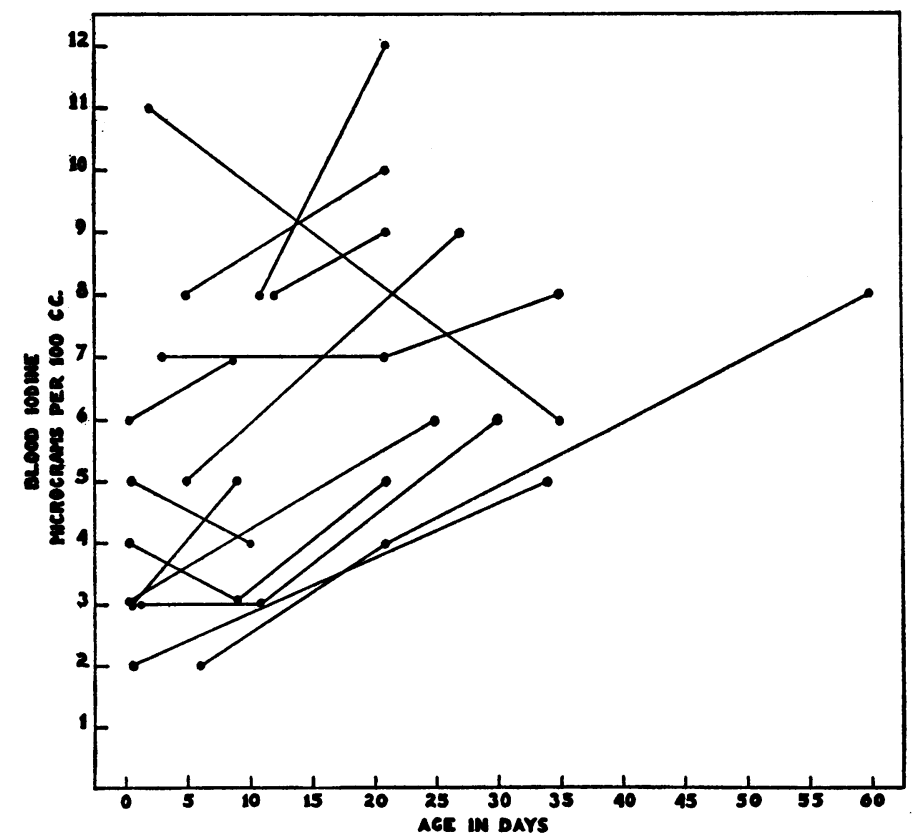

Fig. 2. Successive Determinations of Blood Iodine in Single Infants During the Neonatal Period 
itial level in all but two instances. The explanation for the peculiar behavior of Case 22 (Table I), in which an initial blood iodine of 11.0 micrograms per cent at the age of 2 days fell to a level of 6.0 micrograms at 35 days, is not clear. It would, of course, have been desirable to determine the blood iodine of each infant from day to day during the early weeks of life. Obviously this was inexpedient, since the amount of blood required for a single satisfactory determination represented approximately 3 per cent of the infant's total blood volume.

With the exception of the neonatal period, the blood iodine does not appear to vary consistently with age throughout the remainder of childhood. No significant change in level appears in the prepuberal or early puberal period.

\section{The effect of food intake on blood iodine}

Comparison of the blood iodines of 19 subjects receiving cod liver oil daily (containing approximately 150 micrograms of iodine in addition to food iodine) with those of 20 infants receiving a low iodine diet consisting mainly of milk, revealed no significant difference in the range or average of the iodine values, the means being $6.9 \pm 0.38$ in the former and $6.8 \pm 0.43$ in the latter group. A further observation to determine the effect of feeding on the circulating iodine is illustrated in Figure 3. Specimens of blood

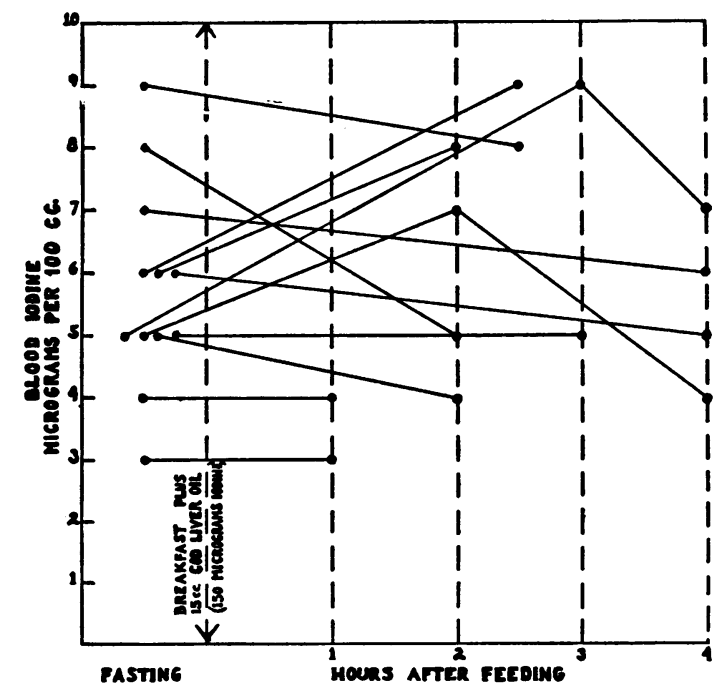

Fig. 3. Effect of High Iodine Feeding on Blood IODINE were obtained from 12 children in the fasting state and again at varying intervals after a breakfast consisting of banana, cereal, milk and $15 \mathrm{cc}$. of cod liver oil containing 8 micrograms of iodine per cc. The results varied widely in different subjects. The two specimens obtained one hour after feeding showed no change in iodine level. Of the four specimens drawn two hours after feeding, two showed a presumably significant rise of 2 micrograms per cent in blood iodine level, one a slight and probably insignificant drop, and one a significant fall of 3 micrograms per cent. The two specimens obtained $2 \frac{1}{2}$ hours after feeding likewise varied markedly; one was 3 micrograms per cent higher than the fasting specimen and the other remained essentially unchanged. The same holds true for the two samples obtained 3 hours after the test meal. Two determinations made 4 hours after the high iodine feeding showed a slight drop considered to be within the limits of error of the analytical procedure.

\section{Relationship between blood iodine and sex}

In a recent publication, Baumann and Metzger (8) have reported significant differences in the range and average value of blood iodine between the sexes in a small series of adults, the average value in males being approximately 33 per cent higher than that in females. Because of these interesting findings, the data in the present study have been grouped according to sex in Figure 4 . It appears that the spread of values in the 50 males is somewhat wider than that in the $50 \mathrm{fe}-$ males and that the mode is distinctly higher in the males than in the females. However, the mean blood iodine in the two groups is identical, namely, 6.2 micrograms per $100 \mathrm{cc}$.

\section{Seasonal variation in blood iodine}

The literature is replete with references to seasonal variations in the blood iodine level. Veil and Sturm (9), Curtis and coworkers (10) and many others have found that the highest values were obtained during the summer months and the lowest in the winter. A tabulation of our data with respect to season appears in Figure 5. Infants below the age of two days were omitted from this tabulation. Although the range of 


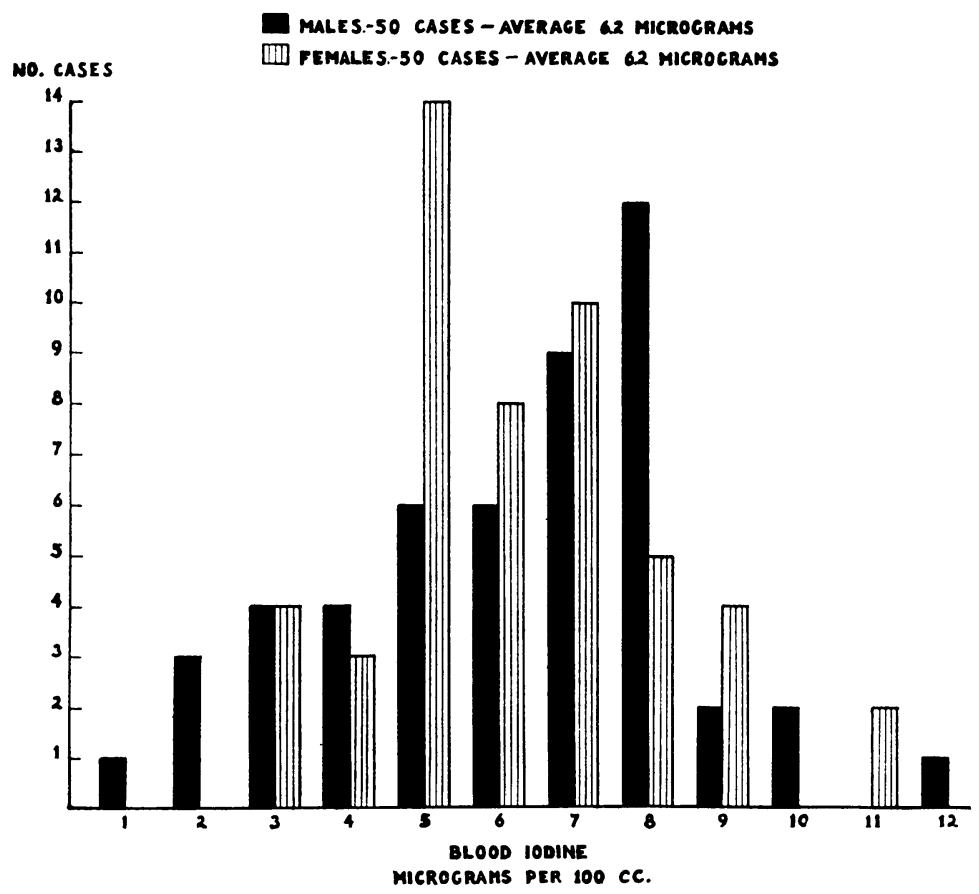

Fitr. 4. Comparison of Blood Iodine of Males and Females

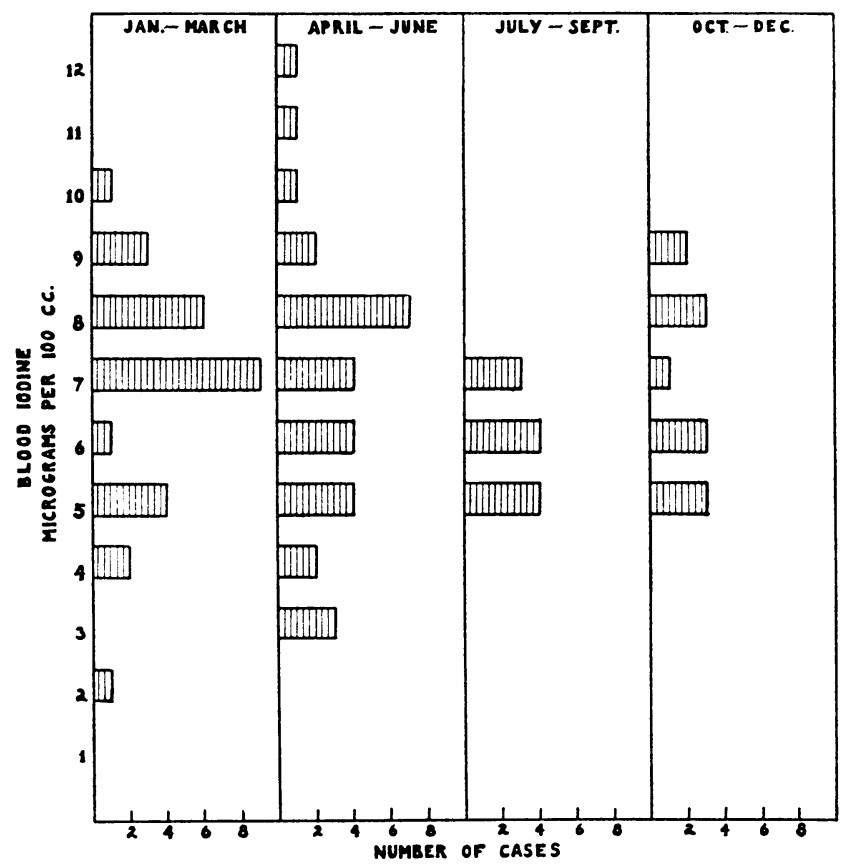

Fig. 5. Seasonal Variation of Blood Iodine 
values appears to be greater from January to June than from July to December, this difference in all probability results from the fact that more cases are reported for the first half of the year. The average values for the blood iodine level in the first, second and fourth quarters of the year agree closely, being 6.8, 6.8 and 6.9 micrograms per $100 \mathrm{cc}$., respectively. The somewhat lower average value of 6.0 micrograms found in the summer period is probably of no significance, since only 11 estimations were made during this season.

\section{Relationship between blood iodine and fever}

In Table II are listed the blood iodine values for 7 patients with temperature elevations from

TABLE II

Influence of fever on blood iodine

\begin{tabular}{|c|c|c|c|c|c|c|}
\hline Case & Sex & Date & Age & $\begin{array}{l}\text { Tem- } \\
\text { per- } \\
\text { ature }\end{array}$ & Diagnosis & $\begin{array}{l}\text { Blood } \\
\text { iodine }\end{array}$ \\
\hline $\begin{array}{l}\text { C.D. } \\
\text { F.G. } \\
\text { F.G. } \\
\text { C.B. } \\
\text { C.B. } \\
\text { E.N. } \\
\text { M.C. } \\
\text { A.L. } \\
\text { S.K. } \\
\text { S.K. }\end{array}$ & $\begin{array}{l}\text { M. } \\
\text { F. } \\
\text { F. } \\
\text { M. } \\
\text { M. } \\
\text { F. } \\
\text { F. } \\
\text { F. } \\
\text { F. } \\
\text { F. }\end{array}$ & \begin{tabular}{|l} 
January 20, 1937 \\
January 6, 1937 \\
January 20,1937 \\
January 7, 1937 \\
January 16, 1937 \\
January 14, 1937 \\
April 13, 1936 \\
Ootober 12,1936 \\
May 8, 1936 \\
June 10, 1936
\end{tabular} & 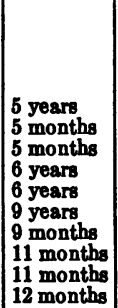 & $\begin{array}{l}{ }^{\circ} \mathrm{C} . \\
\\
40.4 \\
40.1 \\
37.2 \\
40.6 \\
37.4 \\
38.6 \\
39.0 \\
38.8 \\
38.4 \\
37.0\end{array}$ & $\begin{array}{l}\text { Bronchopneumonis } \\
\text { Bronchopneumonia } \\
\text { Convalescent } \\
\text { Bronchopneumonia } \\
\text { Convalescent } \\
\text { Otitis medis } \\
\text { Pyelitis } \\
\text { Cervical adenitis } \\
\text { Mastoiditis } \\
\text { Convalescent }\end{array}$ & $\begin{array}{l}\text { micra } \\
\text { grams } \\
\text { per } 100 \\
\text { ce. } \\
7.0 ; 7.0 \\
\mathbf{5 . 0} \\
\mathbf{5 . 0} ; \mathbf{5 . 0} \\
\mathbf{6 . 0} \\
\mathbf{6 . 0} ; \mathbf{7 . 0} \\
\mathbf{7 . 0} \\
\mathbf{8 . 0} \\
\mathbf{6 . 0} ; \mathbf{6 . 0} \\
\mathbf{5 . 0} \\
\mathbf{7 . 0}\end{array}$ \\
\hline
\end{tabular}

$38.4^{\circ}$ to $40.6^{\circ} \mathrm{C}$. due to various types of infection. In all of these cases the blood iodine was well within the normal range. Samples were obtained from three of the subjects during the convalescent period, after the temperature had been normal for at least five days. No drop in circulating iodine occurred following the cessation of fever; indeed, in the case of S. K. a slight rise from 5 to 7 micrograms per cent was observed.

\section{Blood iodine in thyroid disease}

Unfortunately, the opportunity to study well authenticated thyroid dysfunction presented itself in only a few cases. The protocols of these subjects appear in Table III. Of the three cases of Graves' disease reported, two show blood iodine levels of 11.0 micrograms per $100 \mathrm{cc}$., which is at the upper limit of the normal range; the iodine
TABLE III

Blood iodine in thyroid disease

\begin{tabular}{|c|c|c|c|c|c|c|c|}
\hline Case & Sex & Date & Age & $\begin{array}{c}\text { Basal } \\
\text { met- } \\
\text { abol- } \\
\text { ic } \\
\text { rate }\end{array}$ & $\begin{array}{l}\text { Blood } \\
\text { choles- } \\
\text { terol }\end{array}$ & Diagnosis & $\begin{array}{l}\text { Blood } \\
\text { iodine }\end{array}$ \\
\hline & & & & $\begin{array}{c}\text { per } \\
\text { cent }\end{array}$ & $\begin{array}{c}\text { mom. } \\
\text { per } \\
\text { cent }\end{array}$ & & $\begin{array}{c}\text { micro- } \\
\text { orams } \\
\text { per } 100 \\
\text { ce. }\end{array}$ \\
\hline A.D. & F. & March 8, 1936 & 11 years & +24 & 183 & Graves' disease & 11.0 \\
\hline E.S. & F. & October 3, 1936 & 11 years & +49 & 169 & Graves' disease & 11.0 \\
\hline K.F. & F. & May 25, 1937 & 7 years & +37 & 229 & Graves' disease & 17.0 \\
\hline E.S. & F. & January 27, 1937 & 12 years & -29 & 305 & Postoperative & 4.0 \\
\hline R.F. & F. & May 16, 1936 & 17 months & & 397 & Cretinism & 0 \\
\hline $\begin{array}{l}\text { E.N. } \\
\text { G.B. }\end{array}$ & F. & $\begin{array}{l}\text { November 4, } 1936 \\
\text { October 27, } 1937\end{array}$ & $\begin{array}{l}6 \text { years } \\
4 \text { years }\end{array}$ & -29 & $\begin{array}{l}609 \\
687\end{array}$ & $\begin{array}{l}\text { Cretinism } \\
\text { Cretinism }\end{array}$ & $\begin{array}{l}3.0 \\
3.0\end{array}$ \\
\hline
\end{tabular}

level of the third patient, on the other hand, was distinctly elevated. One of these subjects (E. S.), after having been subjected to subtotal thyroidectomy, developed well defined symptoms of thyroid insufficiency characterized by apathy, listlessness, constipation, loss of appetite, rapidly increasing weight and a fall in basal metabolic rate to -29 per cent. At this point, without thyroid or iodine therapy, her blood iodine was 4.0 micrograms per 100 cc., a drop of 7 micrograms from the preoperative level. The three subjects exhibiting classical signs of cretinism showed iodine levels of $3.0,3.0$ and 4.0 micrograms per $100 \mathrm{cc}$., respectively-values which are at the lower limits of the normal range of this series.

\section{COMMENT}

The average blood iodine of 79 normal children, excluding subjects less than 24 hours old, was 6.6 micrograms per cent, a value which is approximately half of that quoted for adults by Veil and Sturm (9), Curtis and coworkers (1, 10) and Lunde, Closs and Pedersen (11). In a recent study of the blood iodine of 112 normal adults, Perkin, Lahey and Cattell (2), using a dry ashing method, have reported an average value of 6.6 micrograms per $100 \mathrm{cc}$., with a range from 1 to 10 micrograms; their results are in remarkably close agreement with our data.

The many low values found in infants under 24 hours of age and the progressive rise in blood iodine observed in the early days of life are of considerable interest and present a fertile field 
for speculation. It is known from the studies of von Fellenberg (12), Lelkes (13) and others that the thyroid in the newborn contains a very low percentage of iodine in comparison with that of adult glands. Histologically, the glands of infants in the first few days of life show a striking absence of colloid in the follicles and a peculiar desquamation of cells into the lumina of the acini which disappears in the first two weeks of life (20). It is probable that the low blood iodine of newly born babies is intimately associated with these chemical and histological peculiarities of the thyroid gland. Whether the rise in blood iodine in the ensuing days of life represents increased activity of the gland in its extra-uterine environment or merely reflects either a diminished rate of excretion or an inability of the gland to store and utilize iodine, is a question which cannot be answered until more accurate data concerning the chemical nature of the circulating iodine are made available. The studies of Benedict and Talbot (14), Marine and coworkers (15) and Gordon and Levine (16), all of whom found an increased heat production occurring about the second week of life, favor the first supposition; however, as the latter authors have suggested, the observed rise in heat production may be explained on the basis of other extraneous variables such as increased food intake.

The physiological dehydration which occurs in most babies shortly after birth is an uncontrollable factor which must be considered in interpreting the results obtained in the first days of life, since hemoconcentration probably leads to erroneously high values in this period. It is evident, however, that dehydration is not the sole cause for the observed rise in blood iodine in the neonatal period, since the iodine remains stabilized at its higher level long after the transitory dehydration has passed.

The results concerning the effect of food upon circulating iodine, judged by comparing two groups of subjects, one of which received a cod liver oil supplement, appear to indicate that, within the limits of the diets employed, iodine-rich food does not permanently influence the level of the blood iodine. When a high iodine test meal was given, although transitory rises appeared in 4 subjects in 2 to $21 / 2$ hours, there was no consistent variation in the group as a whole. It appears, therefore, that normal subjects are able rapidly to dispose of these amounts of ingested iodine by excretion or storage. However, since temporary alimentary iodemia may occur, the safest procedure to follow in drawing specimens for routine analysis is to obtain the samples from fasting subjects.

Our failure to find a significant change in the level of blood iodine during febrile states is in accord with the findings of Anthes (17), who reported twenty cases of acute and chronic fevers with no concomitant rise in circulating iodine, and contrary to the experience of Curtis et al. who have reported a hyperiodemia in acute severe infections. These results need confirmation on a much larger series of cases but they would seem to imply that the mechanism of fever per se is not associated with an increased outpouring of the thyroid hormone into the blood stream.

Most workers in the field of iodine metabolism agree that although the average blood iodine in a group of hyperthyroid patients is significantly increased above the normal average, from twenty to thirty per cent of such patients exhibit blood iodines within the normal range. This fact is borne out by the few cases of Graves' disease reported here. With regard to hypothyroidism there is less unanimity of opinion. deQuervain and Smith (18), working with a group of cretins in Switzerland, have reported the blood iodines of 11 cretins ranging from 5.0 to 7.5 micrograms per $100 \mathrm{cc}$., in contrast with their normal cases which fell between 14 and 16 micrograms. Elmer and Scheps (19) have also reported mutually exclusive ranges for their cretinous and normal subjects, the former showing iodine levels of from 4 to 7 micrograms per $100 \mathrm{cc}$, and the latter 9 to 18 micrograms. The values found by Curtis and Cole (10) in 8 cretins, on the other hand, were from 5.2 to 9.0 micrograms per 100 cc., which overlapped their reported normal range of 8.5 to 16.2 micrograms. The small series of hypothyroid children reported in this study showed blood iodines which were at the lower limits of our normal range, but which were not lower than several of our normal subjects who exhibited no trace of evidence of thyroid insufficiency. From this, one must conclude that al- 
though a low blood iodine may suggest thyroid hypofunction in the presence of other clinical signs and symptoms, such low values taken alone have very little, if any, diagnostic significance.

\section{SUM MARY}

The blood iodine of 100 normal children, ranging from the moment of birth to the age of 13 years, was determined, by an acid-digestion method, in order to establish normal blood iodine standards in childhood as a prerequisite for further studies in disease. The effect of a number of extraneous variables was also investigated.

In 79 subjects from the age of 2 days to 13 years the blood iodines varied from 3.0 to 12.0 micrograms per $100 \mathrm{cc}$. of whole blood, with an average of $6.6 \pm 0.15$ micrograms; in 21 infants under 24 hours of age the values were significantly lower, ranging from 1.0 to 11.0 micrograms, with an average of $4.7 \pm 0.33$ micrograms.

Successive determinations on single infants revealed that the blood iodine increased with age within the first 2 to 3 weeks of life. No other consistent variations with age were observed.

The blood iodine of subjects receiving a high iodine dietary supplement in the form of cod liver oil was not consistently higher than that of a similar group on a low iodine intake. From two to three hours after an iodine-rich meal, a transitory alimentary hyperiodemia was observed in several instances.

No significant differences in the average blood iodine level were observed between the two sexes in childhood. A seasonal variation in blood iodine could not be substantiated from the reported data.

The level of the circulating iodine was not significantly increased in patients with fever of infectious origin.

Determinations made on patients with known thyroid disease have yielded values which, although suggestively low in hypothyroidism and high in hyperthyroidism, frequently fell within the limits of the normal blood iodine range. Such analyses, therefore, although useful in confirming a clinical impression, have very little absolute diagnostic significance.

\section{BIBLIOGRAPHY}

1. Davis, C. B., Curtis, G. M., and Cole, V. V., Blood iodine studies. II. The normal iodine content of human blood. J. Lab. and Clin. Med., 1934, 19, 818.

2. Perkin, H. J., Lahey, F. H., and Cattell, R. B., Blood iodine studies in relation to thyroid disease. Basic concept of the relation of iodine to the thyroid gland; an iodine tolerance test. New England J. Med., 1936, 214, 45.

3. Fowweather, F. S., The iodine content of the blood of patients suffering from cancer. Brit. J. Exper. Path., 1930, 11, 400.

4. Widmann, E., Zur Methodik der Blutjodbestimmung. Biochem. Ztschr., 1932, 254, 223.

5. Trevorrow, V., and Fashena, G. J., The determination of iodine in biological material. J. Biol. Chem., 1935, 110, 29.

6. Fashena, G. J., and Trevorrow, V., A note on the determination of iodine in biological material. J. Biol. Chem., 1936, 114, 351.

7. Dunn, H. L., Application of statistical methods in physiology. Physiol. Rev., 1929, 9, 275.

8. Baumann, E. J., and Metzger, N., On the amount of iodine in blood. J. Biol. Chem., 1937, 121, 231.

9. Veil, W. H., and Sturm, A., Beiträge zur Kenntnis des Jodstoff wechsels. Deutches Arch. f. klin. Med., 1925, 147, 166.

10. Curtis, G. M., and Cole, V. V., The blood iodine in thyroid disease. Tr. Am. Assoc. Study Goiter, 1934, p. 142.

11. Lunde, G., Closs, K., and Pedersen, O. C., Untersuchungen über den Jodstoff wechsel. III. Untersuchungen über den Blutjodspiegel bei der primären Thyreotoxikose. Biochem. Ztschr., 1929, 206, 261.

12. von Fellenberg, Th., Das Vorkommen, der Kreislauf und der Stoff wechsel des Jods. Ergebn. d. Physiol., 1926, 25, 176.

13. Lelkes, Z., Uber den Jodgehalt der fetalen, Neugeborenen- und Säuglingsschilddrüsen. Endokrinologie, 1933, 13, 35.

14. Benedict, F. G., and Talbot, F. B., The physiology of the new-born infant; character and amount of the katabolism. Carnegie Inst., Wash., 1915, Pub. No. 233.

15. Marine, D., Lowe, B. H., and Cipra, A., Influence of glands with internal secretion on the respiratory exchange. VII. The possible influence of suprarenal involution in new born infants on heat production. J. Metab. Research, 1922, 2, 329.

16. Gordon, H. H., and Levine, S. Z., Respiratory metabolism in infancy and in childhood. XVIII. The respiratory exchange in premature infants-basal metabolism. Am. J. Dis. Child., 1936, 52, 810.

17. Anthes, H., Uber die Frage der Beteiligung der Schilddrüse bei Stoffwechselsteigerungen. I. Bei- 
trage zur Frage des Mechanismus der Stoffwechselsteigerung im Fieber. Deutsches Arch. f. klin. Med., 1933, 176, 128.

18. deQuervain, F., and Smith, W. E., The iodine content of blood in ordinary goitres and in cretinism. Endocrinology, 1928, 12, 177.

19. Elmer, A. W., and Scheps, M., The iodine content of blood and of urine and the basal metabolic rate; their value in the diagnostic of the function of the thyroid gland. Acta med. Scandinav., 1934, 82, 126.

20. Henke, F., and Lubarsch, O., Handbuch der Speziellen pathologischen anatomie und histologie. Band VIII, Springer, Berlin, 1926, p. 11. 